\title{
Coccidia of rabbit: a review
}

\author{
Michal Pakandl
}

Institute of Parasitology, Biology Centre of the Academy of Sciences of the Czech Republic, Branišovská 31, 37005 České Budějovice, Czech Republic

\begin{abstract}
This article summarises the current knowledge of the rabbit coccidia and the disease they cause. Various aspects, such as life cycles, localisation in the host, pathology and pathogenicity, immunity and control, are discussed.
\end{abstract}

Key words: Apicomplexa, rabbit coccidia, review article, life cycles, pathology, immunity, coccidiosis control

\section{INTRODUCTION, HISTORY AND SURVEY OF SPECIES}

This paper reviews the current knowledge of rabbit coccidia. Although rabbits (Oryctolagus cuniculus) can be either host or intermediate host of other coccidia belonging to the genera Cryptosporidium, Besnoitia, Sarcocystis and Toxoplasma, the article deals only with monoxenous coccidia of the genus Eimeria Schneider, 1875.

The chicken coccidia are the mean model in the research of these parasites because of economical importance of the host. Similarly, due to the availability of the host, including inbred and genetically modified strains, important work has been performed on mouse models. In contrast, little attention is currently paid to rabbit coccidia, although these species have also been the subject of many studies and they are of historical importance. According to Levine (1973), Leeuwenhoek observed oocysts in rabbit liver as early as 1674 and hence Eimeria stiedai, a liver coccidium of rabbits, belongs to the first known protozoans. However, coccidia were first studied and described during the 19th century and Eimeria stiedai was the most important subject of such investigations. In 1879 Leuckart (cited according to Levine 1973) distinguished liver and intestinal coccidia of rabbits and named them Coccidium oviforme (now Eimeria stiedai) and Coccidium perforans. During the 20th century, many outstanding coccidiologists, such as Yakimoff, Pellérdy, Cheissin, Rose, Scholtyseck, Coudert, Norton, Gregory, and others studied rabbit coccidia at some period of their scientific life.

The species name $E$. perforans introduced by Leuckart is used till today, but ten other species have been successively distinguished (Coudert et al. 1995, Eckert et al. 1995):
Eimeria coecicola Cheissin, 1947

E. exigua Yakimoff, 1934

E. flavescens Marotel et Guilhon, 1941

E. intestinalis Cheissin, 1948

E. irresidua Kessel et Jankiewicz, 1931

E. magna Pérard, 1925

E. media Kessel, 1929

E. perforans (Leuckart, 1879) Sluiter et Swellengrebel, 1912

E. piriformis Kotlán et Pospesch, 1934

E. vejdovskyi Pakandl, 1988

Eimeria stiedai (Lindemann, 1865) Kisskalt et Hartmann, 1907 is the only liver coccidium.

Carvalho (1942) described Eimeria neoleporis in cottontail rabbits (Sylvilagus floridanus) and reported that this species is easily transferred to tame rabbits (Oryctolagus cuniculus). The oocysts of this species are similar to those of E. coecicola and for this reason Pellérdy (1974) considered the name E. coecicola to be a synonym of E. neoleporis. However, Cheissin (1968) demonstrated the validity of $E$. coecicola using data concerning oocyst morphology as well as endogenous stages. Eimeria neoleporis very probably does not spontaneously occur in tame rabbits. Some other species were also described (cited according to Pellérdy 1974): E. nagpurensis Gill et Ray, 1960, E. oryctolagi Ray et Banik, 1965, and E. matsubayashi Tsunoda, 1952. However, it was shown later that these species are identical with species already described.

Taken together, eleven species of rabbit coccidia listed above seem valid and this is in agreement with the opinion of Coudert et al. (1995), who also prepared a reliable key for species identification (Eckert et al. 1995). 
Table 1. Localisation of rabbit intestinal coccidia in the host and number of their asexual generations.

\begin{tabular}{|c|c|c|c|c|}
\hline Species & $\begin{array}{l}\text { Intestinal segment } \\
(\text { except } E \text {. stiedai) }\end{array}$ & $\begin{array}{l}\text { Localisation in the mucosa } \\
\text { (except } E \text {. stiedai) }\end{array}$ & $\begin{array}{l}\text { No. asexual } \\
\text { generations }\end{array}$ & Reference \\
\hline E. coecicola & appendix, sacculus rotundus, Peyer's patches & $\begin{array}{l}\text { 1st AG in GALT; 2nd-4th AG } \\
\text { and gamogony in epithelium } \\
\text { of domes and mushrooms }\end{array}$ & 4 & Pakandl et al. 1993, 1996a \\
\hline E. exigua & $\begin{array}{l}\text { duodenum-ileum; successively moves from } \\
\text { proximal to distal parts of the small intestine }\end{array}$ & tops of the villi & 4 & Jelínková et al. 2008 \\
\hline E. flavescens & 1st AG small intestine, 2nd-5th AG caecum & $\begin{array}{l}\text { 1st AG in crypts; 2nd-4th } \\
\text { AG in superficial epithelium; } \\
\text { 5th AG and gamonts in crypts }\end{array}$ & 5 & $\begin{array}{l}\text { Norton et al. 1979, Gre- } \\
\text { gory and Catchpole 1986, } \\
\text { Pakandl et al. } 2003\end{array}$ \\
\hline E. intestinalis & lower jejunum and ileum & $\begin{array}{l}\text { 1st and 2nd AG in crypts; } \\
\text { 3rd and 4th AG and gamonts in } \\
\text { crypts and wall of the villi }\end{array}$ & $3-4$ & Licois et al. 1992 \\
\hline E. irresidua & jejunum and ileum & $\begin{array}{l}\text { 1st AG in crypts; } 2 \text { nd AG in lamina } \\
\text { propria; } 3 \text { rd AG, } 4 \text { th AG and game- } \\
\text { tocytes in the villous epithelium }\end{array}$ & 4 & Norton et al. 1979 \\
\hline E. magna & $\begin{array}{l}\text { jejunum and ileum, } \\
\text { in a lesser extent duodenum }\end{array}$ & intestinal villi (walls and tops)* & 4 & $\begin{array}{l}\text { Ryley and Robinson 1976, } \\
\text { Pakandl et al. 1996b }\end{array}$ \\
\hline E. media & $\begin{array}{l}\text { duodenum-jejunum, low concentra- } \\
\text { tion of the parasite in the ileum }\end{array}$ & intestinal villi (walls and tops) & 3 & Pakandl et al. 1996c \\
\hline E. perforans & $\begin{array}{l}\text { maximal parasite concentration in the duo- } \\
\text { denum, but also in the jejunum and ileum }\end{array}$ & both villi and crypts & 2 & Streun et al. 1979 \\
\hline E. piriformis & colon & crypts & 4 & Pakandl and Jelínková 2006 \\
\hline E. vejdovskyi & ileum & $\begin{array}{l}\text { 1st-3rd AG in crypts; } \\
\text { 4th and } 5 \text { th AG in villi }\end{array}$ & 5 & Pakandl and Coudert 1999 \\
\hline E. stiedai & liver & epithelium of biliary ducts & $5-6$ & Pellérdy and Dürr 1970 \\
\hline
\end{tabular}

AG - asexual generation; GALT - gut-associated lymphoid tissue; *according to Ryley and Robinson (1976), only the 1st AG is located in crypts, while Pakandl et al. (1996b) found only the 4th. AG in the crypts and other stages in the villous epithelium.

Although life cycles and localisation of rabbit coccidia were also described by other authors, such as Rutherford (1943), Cheissin (1940, 1947a, b, 1948, 1960), and Pellérdy and Babos (1953), only more recent data obtained under controlled conditions in coccidia-free rabbits are considered.

\section{LOCALISATION IN THE INTESTINE}

Rabbit coccidia parasitize distinct parts of the intestine and in different depths of the mucosa (Table 1). Their sites of development overlap in some cases, but despite this it seems that individual species mostly inhabit different "niches". I believe that this term, which is used in ecology, describes well the situation.

\section{LIFE CYCLES}

The life cycles of rabbit coccidia do not differ extensively from those of other coccidia of the genus Eimeria. The number of asexual generations (AG) is fixed and characteristic for individual species. However, there are some peculiarities in rabbit coccidia; the most prominent is the migration of sporozoites from the site of entry to the target site, which also occurs in chicken, goat and other animals, but in rabbit coccidia, especially in E. coecicola and E. stiedai, exhibits unique features. The second one is the presence of two types of meronts and merozoites.

\subsection{Migration OF SPOROzoites}

Drouet-Viard et al. (1994) found sporozoites of E. intestinalis within less than 10 min after inoculation in the duodenal mucosa and $4 \mathrm{~h}$ later the sporozoites were seen in the ileum, the specific site of parasite development. Pakandl et al. (1993, 1996a) studied endogenous development of E. coecicola. Although 1 st AG of this coccidium develops in gut-associated lymphoid tissue (GALT) and other stages in the epithelium of vermiform appendix, sacculus rotundus and Peyer's patches, the sporozoites first penetrate the small intestine and were found in their specific site of multiplication as late as $48 \mathrm{~h}$ post-inoculation (p.i.). Similar results were obtained after infection with E. magna (Pakandl et al. 1995), the sporozoites of which migrate from the duodenum to the jejunum and, more abundantly, to the ileum. Immunohistochemistry was used to check for sporozoite migration after infection with E. coecicola and E. intestinalis (Pakandl et al. 2006). While sporozoites of E. coecicola were found in extraintestinal localisation, mesenteric lymph nodes (MLN) and spleen, no parasite stages were found in these organs after infection with $E$. intestinalis. The sporozoites of $E$. coecicola apparently migrate extraintestinally, probably via lymphatic system. The reasons for such migration may be the development in distinct parts of the intestine (appendix, sacculus rotundus and Peyer's patches) and unusual localisation of the first AG in lymphoid cells beneath the epithelium. The route of migration of E. intestinalis, as well as other rabbit intestinal coccidia (except E. coecicola), is an enigma and probably differs from that of $E$. coecicola, because no sporozoites of E. intestinalis were found in extraintestinal localisation (Pakandl et al. 2006), although they have been observed in intraepithelial lymphocytes (IELs) (Licois et al. 1992).

In some respects, the migration of sporozoites of rabbit coccidia resembles the invasion of host tissues in chickens. The sporozoites of the chicken coccidium Eimeria tenella first penetrate the enterocytes in the caecal surface epithelium and thereafter enter IELs. These cells leave the 
epithelium and the sporozoites are transported by them via the lamina propria into the epithelium of crypts (Lawn and Rose 1982). Fernando et al. (1987) observed similar migration in other species of chicken coccidia, irrespective whether their initial development occurs in the crypts (E. acervulina and E. maxima) or in superficial epithelium (E. praecox and E. bruneti).

Taken together, sporozoites of chicken species penetrate into the same intestinal segment in which, after migration, they subsequently develop. In contrast, the small intestine, especially the duodenum, seems to be a universal gate for rabbit coccidia, regardless of the specific site of their further development.

Migration is apparently not limited to sporozoites. Norton et al. (1979) and Pakandl et al. (2003) showed that first-generation meronts of E. flavescens parasitize in the small intestine, while the rest of the endogenous development takes place in the caecum. Hence, the merozoites must undergo a long-distance migration.

Eimeria stiedai develops in the epithelium of bile ducts and therefore several researchers searched for the route of their migration from the duodenum to liver. Smetana (1933a) considered the possibility of traffic via the portal vein as well as the lymphatic system. Several authors (Smetana 1933a, Horton 1967, Fitzgerald 1970, Pellérdy and Dürr 1970) found sporozoites of E. stiedai within lymphoid cells in MLN. The way of their further migration is unclear. Horton (1967) and Fitzgerald (1970) suppose that the sporozoites may be transported to the liver via the blood, but Dür (1972) assumes the transport of sporozoites from MLN to blood is improbable and supposes that the parasite cells are spread throughout the whole host organism and after this they settle in the liver. This hypothesis is corroborated by the finding of sporozoites in bone marrow and measurement of radioactivity after infection with radioactive-labelled sporozoites (Dürr 1972).

It is unclear what the true meaning of parasite migration is during early events in the endogenous parts of the life cycle. In two species, E. stiedai that develops in liver and E. coecicola parasitizing in three anatomically distinct parts of the intestine, which however, share similar structure and function and are parts of GALT, the migration seems to be necessary. Nevertheless, the other species migrate as well and the biological importance of this process may be only a subject of speculation. Perhaps it is an inheritance from an unknown ancestor with more complex life cycle or such traffic is important for the parasite to find its specific site of development. As mentioned above, sporozoites of chicken coccidia also migrate in the host mucosa and there is even evidence of their extra intestinal localisation (Long and Millard 1979, Kogut and Long 1984, Al-Attar and Fernando 1987, Fernando et al. 1987). Patent infection appeared in coccidia-free recipients after infection with blood and homogenates from liver, spleen and other organs of infected donors. Ball et al. (1990) ob- tained similar results in mice and Renaux et al. (2001) in rabbits. Unfortunately, such experiments cannot on principle show how large a portion of sporozoites penetrate outside the intestine. Taken together, it seems sure that the extraintestinal migration of sporozoites of E. coecicola and E. stiedai is an essential part of their cycles. On the other hand, this is not clear in the other rabbit coccidia and coccidia of the genus Eimeria from chicken and other hosts. Regarding the observations that the sporozoites of rabbit coccidia enter another part of the intestine than that in which further development takes place, it may be concluded that their route of migration remains unclear.

\subsection{Polynucleate merozoites}

Two types of meronts were noted in rabbit coccidia in the past. Rutherford (1943) described life cycles of E. irresidua, E. magna, E. media and E. perforans and Cheissin $(1940,1948)$ worked with E. magna and E. intestinalis. Although these authors did not mention polynucleate merozoites, they remarked two types of meronts and merozoites in AG of rabbit coccidia.

Polynucleate merozoites were later found in all rabbit coccidia except E. irresidua. However, the endogenous development of this species has never been studied using electron microscopy. Some authors studied only part of the endogenous development, but when the whole life cycle was investigated, polynucleate merozoites were present besides uninucleate ones in all AG. The only exception is the 1 st and 2 nd AG of E. coecicola (Pakandl et al. 1993). For a survey see Table 2.

Polynucleate merozoites are characteristic of rabbit coccidia and so far this stage has not been found in other coccidia. Such merozoites differ from uninucleate ones in number of nuclei and in the presence of some structures belonging to newly formed merozoites, namely inner membranous complex, rhoptry anlage and, sometimes, conoid (Danforth and Hammond 1972, Pakandl et al. 1996a). The polynucleate merozoites resemble "sporozoite-like schizonts" found in the rabbit coccidia E. magna (Pakandl et al. 1996b), E. media (Pakandl et al. 1996c), E. vejdovskyi (Pakandl and Coudert 1999) and E. flavescens (Pakandl 2005). This stage develops from a sporozoite, in which characteristic organelles such as three-layered pellicle and apical complex are conserved, but nuclear division and the initial formation of merozoites already begins. "Sporozoite-like schizonts" were also found in coccidia from other hosts, such as Eimeria auburnensis and E. alabamensis from calves (Clark and Hammond 1969, Sampson and Hammond 1970) and E. bilamellata, E. callospermophili and E. larimensis from the uinta ground squirrel Spermophilus armatus (Roberts et al. 1970, Speer and Hammond 1970, Speer et al. 1970).

What is the role of polynucleate merozoites in the life cycles of rabbit coccidia? The fact that these stages were found in almost all rabbit coccidia and AG shows that it 
Table 2. Findings of polynucleate merozoites in rabbit coccidia.

\begin{tabular}{lll}
\hline Species & Stage(s) studied and polynucleate merozoites found & Reference \\
\hline E. coecicola & whole EC; polynucleate merozoites found only in the 3rd and 4th AG & Pakandl et al. 1993, 1996a \\
E. exigua & whole EC & Jelínková et al. 2008 \\
E. flavescens & whole EC; polynucleate merozoites found only when the 5th AG develops & Norton et al. 1979 \\
& whole EC & Pakandl et al. 2003, Pakandl 2005 \\
E. intestinalis & whole EC & Licois et al. 1992 \\
E. magna & probably 3rd AG (5 days after inoculation) & Sénaud and Černá 1969 \\
& probably 3rd AG (4 days after inoculation) & Danforth and Hammond 1972 \\
& whole EC & Ryley and Robinson 1976 \\
& whole EC & Pakandl et al. 1996b \\
& whole EC & Cheissin 1960 \\
E. media & whole EC & Pakandl 1988 \\
& whole EC & Pakandl et al. 1996c \\
E. perforans & whole EC & Streun et al. 1979 \\
E. piriformis & whole EC & Pakandl and Jelínková 2006 \\
E. stiedai & whole EC & Pellérdy and Dürr 1970 \\
& probably the last AG (13 days after inoculation) & Cerná and Sénaud 1971 \\
E. vejdovskyi & whole EC & Pakandl 1988, Pakandl and Coudert 1999 \\
\hline
\end{tabular}

$\mathrm{AG}$ - asexual generation; $\mathrm{EC}$ - endogenous cycle

is an integral part of their life cycle. Cheissin (1967) believes that the presence of two types of meronts in the second AG of E. magna reflects sexual dimorphism. This is also proposed by Pellérdy and Dürr (1970). Streun et al. (1979) postulated that there are two lines in the endogenous development of E. perforans: the male, represented by meronts forming polynucleate merozoites in which endomerogony (formation of daughter merozoites inside the cells as mentioned above) occurs, whereas the female line is characterised by uninucleate merozoites arising by ectomerogony (merozoites are formed in contact with plasmalemma of the meront; later they protrude into parasitophorous vacuole and mature merozoites are constricted from the mother cell). The last male (polynucleate) merozoites give rise to microgamonts and the female (uninucleate) ones to macrogamonts. Streun et al. (1979) named meronts producing polynucleate merozoites and these merozoites themselves as type A; the second being type B. This is the terminology that will be used in this review as well.

Streun et al. (1979) observed that as the endogenous development progresses, the number of type A meronts decreases in subsequent generations. The fact that the microgamonts are less numerous than macrogamonts is inherent with this observation. The same is applicable for E. flavescens (Pakandl et al. 2003), E. intestinalis (Licois et al. 1992), E. magna (Pakandl et al. 1996b) E. media (Pakandl et al. 1996c), and E. vejdovskyi (Pakandl and Coudert 1999). Moreover, the suppression of the fourth $\mathrm{AG}$, in which type $\mathrm{B}$ meronts give rise to larger numbers of merozoites than those of type $\mathrm{A}$, in the precocious line of E. flavescens resulted in the enhanced proportions of type A meronts in the fifth AG and microgamonts as compared with those of the parent strain. This result seems to corroborate the hypothesis pronounced by Streun et al. (1979). On the other hand, very low proportion of the meronts producing polynucleate merozoites in E. piriformis (Pakandl and Jelínková 2006) is not in agreement with the hypothesis that those meronts precede microgamonts.

If the scheme of the life cycle proposed by Streun et al. (1979) is true, even the sporozoites, meronts and merozoites must be sexually determined. However, this hypothesis seems to be in contradiction with the fact that patent infection can be obtained after inoculation of chickens with single sporocyst or sporozoite (Lee et al. 1977, Shirley and Harvey 1996) or mice with single merozoite (Haberkorn 1970). For this reason, it is generally supposed that the development of the endogenous stages into macro- or microgamonts is induced by environmental factors rather than genetically determined. But the rabbit may be an exception. Numerous attempts to obtain oocyst production for E. intestinalis have been carried out in SPF rabbit by inoculating single sporozoite or even single sporocyst, without success (Licois, pers. comm.). Smith et al. (2002) reviewed various aspects of sexual determination in Apicomplexa. It seems that the commitment to male or female gametocytogenesis occurs at various points of the asexual phase of their endogenous cycles (i.e. not during formation of sporozoites), since there is evidence that meronts of E. tenella and Toxoplasma gondii and cysts of Sarcocystis cruzi are differentiated and contain only merozoites or cystozoites of the same type as shown by use of cytochemistry.

The development of polynucleate merozoites raises some questions. It is uncertain whether (i) type A merozoites leave the host cell and enter another one to give rise to new meronts or whether (ii) the new merozoites are formed within the same parasitophorous vacuole. Speer et al. (1973) observed polynucleate merozoites of E. magna in tissue cultures and showed that both alternatives are possible. Theoretically, polynucleate merozoites are able 
to enter another host cell, because their apical complex is fully developed. On the other hand, the beginning of formation of new merozoites was seen within polynucleate merozoites of E. magna (Danforth and Hammond 1972) and E. coecicola (Pakandl et al. 1996a). Pakandl (2005) observed a continuation of this process, protruding of apical ends of new merozoites into parasitophorous vacuole, in E. flavescens. Hence, new, and very probably uninucleate, merozoites may be formed within the same parasitophorous vacuole. The fate of these putative uninucleate merozoites arising from type A merozoites is unclear. However, they could give rise to new meronts, perhaps of the type A if two lines in the endogenous development exist.

In addition, it is not sure whether (i) several nuclei are originally incorporated into polynucleate merozoites during their formation or (ii) if only a single nucleus consequently undergoes division within the merozoite. Pakandl (2005) saw nuclear division inside the merozoites of E. flavescens. Both types of meronts may be easily recognised in the last AG, as they differ in the number and size of merozoites. Some huge merozoites, apparently of the type A, harboured only one nucleus and hence nuclear division must take place inside the merozoite during the following development. Hence, this can be seen as evidence supporting the second hypothesis.

It could be objected that at least part of type B merozoites might arise from type A merozoites (which are in fact meronts) and thus the differentiation of A and B meronts and merozoites in the endogenous development is not correct. However, the number of type B merozoites in one meront is, in the majority of cases, much higher then the number of nuclei in the type A merozoites, in which the highest number of nuclei, up to 12, was found in the fifth AG of E. flavescens (Pakandl 2005). Moreover, the number of A meronts is usually considerably lower than that of $\mathrm{B}$ meronts in rabbit coccidia and indeed it is impossible that the A merozoites form B meronts.

\subsection{BIOLOGICAL FEATURES OF DIFFERENT SPECIES RELATED TO LIFE CYCLES AND LOCALISATION}

\subsubsection{Oocyst production, reproductive potential and prepatent period}

Coudert et al. (1995) compared total oocyst yield after experimental infection of rabbits with coccidia. The minimum numbers of oocysts for inoculation to obtain maximum yield were as follows: 80 for E. magna, 100 for E. flavescens and E. irresidua, 200 for E. perforans and E. media, 500 for E. coecicola, $10^{3}$ for E. exigua, E. intestinalis and E. vejdovskyi and $10^{4}$ for E. piriformis. In most of the species, the total number of oocysts per rabbit that can be recovered is between $1-5 \times 10^{8}$. Two coccidia are able to produce more oocysts per rabbit: $E$. vejdovskyi $10-15 \times 10^{8}$ and E. intestinalis 30-50 $\times 10^{8}$. Perhaps the localisation of gamogony in the villi of the lower part of the small intestine enhances the total oocyst output, since gamogony of $E$. vejdovskyi takes place in the villi of the ileum (Pakandl and Coudert 1999) and E. intestinalis parasitizes in the lower jejunum and ileum in both crypts and villi (Peeters et al. 1984a, Licois et al. 1992).

Not surprisingly, the life cycle characterised by the number of $\mathrm{AG}$ and the number of merozoites produced by type $\mathrm{B}$ meronts in each generation influences the prepatent period (PP) and reproductive potential (RP) characterised by the oocyst yield for one oocyst inoculated to one rabbit. For example, there are only two and three AG in the life cycle of E. perforans (Streun et al. 1979) and E. media (Pakandl et al. 1996c), respectively, and these species have the shortest PP: 5 (E. perforans) and 4.5 (E. media) days. In contrast, E. vejdovskyi, the rabbit intestinal coccidium with the longest PP (10 days), forms five AG during its endogenous development (Pakandl and Coudert 1999) and the liver coccidium E. stiedai with PP 14 days has 5-6 AG in its life cycle (Pellérdy and Dürr 1970).

The RP assessed by the criterion mentioned above varies in most of the intestinal coccidia between $1-5 \times 10^{6}$ (Coudert et al. 1995). In E. stiedai it is difficult to determine the RP because oocysts are trapped in biliary ducts. Eimeria exigua and E. piriformis exhibit a considerably lower RP $\left(1-2 \times 10^{5}\right.$ and $1.5-2.5 \times 10^{4}$, respectively). Both species form $4 \mathrm{AG}$; only small meronts producing a small number of merozoites develop in E. exigua and the 1 st and 3rd generation meronts of E. piriformis form only two merozoites. Thus, RP may depend on peculiarities in the life cycles of individual species.

As stated by Coudert et al. (1995), there is no correlation between oocyst excretion and severity of the disease. For example, infection of a naïve rabbit with 100 oocysts of $E$. flavescens is sufficient to give maximum oocyst yield $\left(1-2 \times 10^{8}\right)$ and increasing the infective dose does not result in enhanced oocyst output. However, this dose does not cause any symptoms of a disease. On the contrary, if the intestinal mucosa is heavily damaged during severe disease, oocyst production may be even decreased (Ryley and Robinson, 1976, Norton et al. 1979). Moreover, oocyst production often markedly varies between individual animals under identical experimental conditions (Ryley and Robinson, 1976, Pakandl, unpubl. results, Coudert, pers. comm.).

\subsubsection{Localisation and pathogenicity}

On the basis of experiments performed on laboratory SPF rabbits, Coudert et al. (1995) classified coccidia into five groups according to their pathogenicity: non pathogenic (E. coecicola), slightly pathogenic (E. perforans, E. exigua and E. vejdovskyi), mildly pathogenic or pathogenic (E. media, E. magna, E. piriformis and E. irresidua), highly pathogenic (E. intestinalis and E. flavescens), and 
species with "pathogenicity depending on the infective dose" (E. stiedai). This formulation means that E. stiedai exhibits, due to its localisation, some peculiarities and not that pathogenic effect in the intestinal coccidia is not dose-dependent.

The pathogenicity seems to be connected, at least partially, to the localisation of the coccidia. The most pathogenic rabbit coccidia, E. intestinalis and E. flavescens, parasitize the crypts of lower part of the small intestine or caecum, respectively (Norton et al. 1979, Licois et al. 1992, Pakandl et al. 2003). The intestinal epithelium is apparently more heavily damaged if the parasite destroys the stem cells located in the crypts. Gregory and Catchpole (1986) believe that destruction of crypts caused by $E$. flavescens is a crucial factor in the severity of the lesions. Among other species, classified by Coudert et al. (1995) as pathogenic, the endogenous development, at least the last merogony and gamogony, of E. irresidua, E. magna and E. piriformis, takes place in crypts (for citations see Tab. 1). With the exception of E. perforans, which develops both in crypts and in villi, the slightly or non pathogenic species parasitize the intestinal villi.

Histopathological findings sometimes do not correlate with pathogenicity evaluated by the criteria such as mortality, weight gains and clinical signs. For example, E. coecicola causes severe lesions in the appendix (Vítovec and Pakandl 1989), but in terms of its influence on the entire organism, it is non pathogenic.

\subsubsection{Distribution in the mucosa}

Sporozoites of some rabbit coccidia migrate towards intestinal crypts and first generation meronts develop there. This was observed in E. intestinalis (Licois et al. 1992, Pakandl et al. 2006), E. piriformis (Pakandl and Jelínková 2006), and E. vejdovskyi (Pakandl and Coudert 1999). In this case, the second and sometimes the following generation meronts plentifully occur in one crypt, whereas often no parasite stages are found in the neighbouring crypts, as the merozoites arising from the first generation probably do not migrate far and enter host cells in their proximity, giving rise to the next AG. Such an accumulation of parasite stages was not observed in other coccidia, such as E. exigua, E. magna and E. media (Pakandl et al. 1996b, c, Jelínková et al. 2008), the development of which begins in upper area of the mucosa.

\subsection{Changes IN THE LIFE CYCLES - SELECTION FOR PRECOCIOUSNESS}

In order to avoid continuous medication of chickens with anticoccidial drugs, different vaccination strategies have been developed. The most important in practice is currently vaccination with attenuated lines of coccidia. These lines were derived using two methods: adaptation to chicken embryos or selection for precocious development, which results in shortening of the prepatent period
Table 3. Precocious lines of rabbit coccidia.

\begin{tabular}{|c|c|c|c|c|}
\hline Species & $\begin{array}{l}\text { Shortening } \\
\text { of the prepat- } \\
\text { ent period }\end{array}$ & $\begin{array}{c}\text { No. } \\
\text { passages } \\
\text { needed }\end{array}$ & $\begin{array}{l}\text { Changes in the } \\
\text { endogenous } \\
\text { development }\end{array}$ & Reference \\
\hline E. coecicola & 3.5 days & $*$ & $*$ & $\begin{array}{l}\text { Coudert et } \\
\text { al. } 1995\end{array}$ \\
\hline E. flavescens & 67 hours & 19 & $\begin{array}{l}\text { 2nd (or 3rd) and } \\
\text { 4th AG are absent }\end{array}$ & Pakandl 2005 \\
\hline E. intestinalis & $\leq 71$ hours & 6 & $\begin{array}{l}\text { probably the } 3 \text { rd } \\
\text { AG is absent }\end{array}$ & $\begin{array}{l}\text { Licois et } \\
\text { al. } 1990\end{array}$ \\
\hline E. magna & 46 hours & 8 & $\begin{array}{l}\text { the last ( } 4 \text { th) } \\
\text { AG is absent }\end{array}$ & $\begin{array}{l}\text { Licois et al. } \\
\text { 1995, Pakandl } \\
\text { et al. } 1996 b\end{array}$ \\
\hline E. media & 36 hours & 12 & $\begin{array}{l}\text { the last (3rd) } \\
\mathrm{AG} \text { is absent }\end{array}$ & $\begin{array}{l}\text { Licois et al. } \\
\text { 1994, Pakandl } \\
\text { et al. 1996c }\end{array}$ \\
\hline E. piriformis & 24 hours & 12 & $\begin{array}{l}\text { the last ( } 4 \text { th) } \\
\text { AG is absent }\end{array}$ & $\begin{array}{l}\text { Pakandl and } \\
\text { Jelínková } \\
2006\end{array}$ \\
\hline
\end{tabular}

* no details were published; AG - asexual generation

(Shirley and Long 1990). Both adaptation to embryos and precociousness are usually accompanied by the reduction of reproductive potential and pathogenicity of coccidia. The fact that the selection pressure during a relatively low number of passages leads to genetically stable changes (Jeffers 1975) is surprising. However, the genetic background of this phenomenon remains unclear.

Precocious lines (PL) were selected in rabbit coccidia (Table 3 ). The shortening of PP is caused by the absence of one or more asexual generations and not by accelerated development of individual stages.

The absence of some AG leads to reduced reproductive potential, usually $500-1,000$ times. Unlike to chicken coccidia, the oocysts of precocious lines, with exception of $E$. flavescens, can be recognised by the oocyst morphology. Using light microscope, two refractile bodies (RB), each of them belonging to one of two sporozoites, can be seen within each sporocyst in original strains (OS). In the oocysts of the PL of E. intestinalis, two sporocysts lack $\mathrm{RB}$, and two remaining sporocysts possess one huge RB (Licois et al. 1990). In PL of E. magna, E. media and E. piriformis, each sporocyst contains one large RB (Licois et al. 1994, 1995, Pakandl and Jelínková 2006). This last same feature is encountered also for E. coecicola (data not published). Electron-microscopic studies (Pakandl et al. 2001) revealed that the extremely large RB can be found either inside one of the sporozoites, or free inside the sporocyst. In E. piriformis, RB, when outside the sporozoites, is included in the sporocysts residual body (Pakandl and Jelínková 2006). Sporozoites of PL of E. intestinalis, E. magna and E. media contained no, or very small, RB after in vitro excystation (Pakandl et al. 2001) and free large RB were seen inside as well as outside the sporocysts. It is unclear how the RB can leave the cell without its fatal damage and why the free RB can be conserved, as no membrane or other structure surrounding it can be observed by transmission electron microscopy. It was observed in the original strains of E. magna and E. media 
(Pakandl et al. 1996a, c) that the RB of sporozoites is distributed into the first generation merozoites and even the merozoites of the second generation may contain small RB. Since excysted sporozoites of PL lack RB, it is absent in merozoites as well hence even the first and sometimes second generation merozoites differ in OS and PL.

\section{Pathology and pathogenicity}

Individual species of rabbit coccidia differ in their pathogenicity. It should be pointed out that weight gain is simple, but is the most reliable criterion of health status of animals and to measure the intensity of infection in growing rabbits.

While there is no correlation between oocyst production and the dose inoculated, unless very small doses are used, the severity of the disease varies according to the infective dose as it is reported in several papers dealing with experimental coccidiosis (Licois et al. 1995, Norton et al. 1979, Gregory and Catchpole 1986, Coudert et al. 1993).

Histopathology of infection with E. stiedai was described by Smetana (1933b) and pathogenesis was characterised by Pellérdy (1974). Biliary duct epithelium proliferates and the proliferating cells fill the lumina of distended biliary capillaries. The biliary vessels are abnormally distended and filled with detritus and parasite stages. Nodules surrounded by infiltrating inflammatory cells appear in the parenchyma. The damaged parenchyma is replaced by fibrous tissue. The disease leads to extreme enlargement of the liver and yellowish nodules are post-mortem macroscopically visible.

Later the metabolic changes were characterised using serum parameters: increased activity of sorbit dehydrogenase, glutamate oxalate transaminase, glutamate pyruvate transaminase, glutamate dehydrogenase, $\gamma$-glutamyl tranferase and glutamic oxalacetic transaminase, as well as bilirubinaemia and lipaemia, are characteristic for the infection (Hein and Lämmler 1978, Barriga and Arnoni 1979, 1981). Barriga and Arnoni (1979) recorded high mortality $(80 \%$ and $40 \%)$ after infection with $10^{5}$ and $10^{4}$ oocysts, respectively.

Intestinal coccidia cause more or less severe disease in rabbits, depending mainly on the infective dose, parasite species, immune status and age of animals. Characteristic symptoms of intestinal coccidiosis are diarrhoea, lost of weight and sometimes mortality. Food intake and faecal excretion are reduced. There is generally no dehydration of the whole organism, but ion metabolism is affected and faecal losses of potassium lead to hypokalaemia in blood plasma (Licois et al. 1978a, b, Peeters et al. 1984a). Spectacular, but only over the course of a few days lasting, lesions occur mostly during gamogony phase of the parasite development. Enteritis caused by coccidia is often accompanied by marked increasing of the number of Escherichia coli and rotavirus in the host intestine (Licois and Guillot 1980, Peeters et al. 1984a, b) and hence the interplay between pathogens may be important under field conditions.

Two detailed studies of pathomorphological changes caused by the two most pathogenic rabbit coccidia were published. After experimental infection with E. intestinalis, Peeters et al. (1984a) observed severe villous atrophy from day 7 to 10 p.i. The ileal villi, which were finger- or tongue-shaped in non-infected controls, changed to leafshaped. At 216 h p.i., most villi and the whole mucosa were severely swollen. The epithelial cells were mostly detached and the microvilli became irregular, thickened and stunted. However, as soon as the parasite development was almost finished, i.e. about day 12 p.i., the mucosa regained an outwardly normal morphological pattern. Gregory and Catchpole (1986) characterised pathological changes in heavy infections with $E$. flavescens as invasion of caecal epithelium with parasite stages, loss of surface epithelium as a normal process in cell turnover, failure of infected crypts to replace the lost surface epithelium, resulting in wide spread denudation of caecal mucosa, severe inflammation of the denuded caecal wall and finally some reparative changes. According to Gregory and Catchpole (1986), death was apparently due to a combination of dehydration and tissue invasion by bacteria.

\section{INFECTIVITY OF COCCIDIA IN SUCKLING RABBITS}

Generally, rabbits younger than 20 days cannot be infected with coccidia (Coudert et al. 1991, Pakandl and Hlásková 2007). Dürr and Pellérdy (1969) were able to infect sucklings from the first to the ninth day of age, but they had to use a very large dose of oocysts of the liver coccidium E. stiedai or of intestinal coccidia. Despite of this, oocyst shedding was very low, especially after infection with intestinal species. Pakandl and Hlásková (2007) showed that the oocyst production in suckling rabbits infected with E. flavescens and E. intestinalis increased with the age of animals. A large difference was observed namely between rabbits inoculated at 19 and 22 days of age. At this age, the sucklings, in addition to milk, usually begin to consume plant feed and this leads to changes in the intestinal environment. Rose (1973) suggests that inefficiency of excystation and other factors, namely the deficiency of paraaminobenzoic acid in mother milk, contribute to the innate resistance to coccidia in very young mammals.

\section{IMMUNITY}

It is commonly accepted that the local immune response mediated by gut-associated lymphoid tissue (GALT) plays more important role in immunity to coccidiosis than the systemic response. In rabbits, GALT involves appendix, sacculus rotundus, Peyer's patches (PP), IELs and lamina propria leukocytes (LPL). The intestinal immune system successively matures from birth to adulthood. The appendix plays crucial role in the immune sys- 
tem of lagomorphs. In terms of structure and function, it does not share characteristics with other mammals. The young rabbit appendix is involved in diversification of the B-cell antibody repertoire (Weinstein et al. 1994, Mage 1998a) and therefore this organ is considered to be a bursal equivalent. Ig gene diversification in the rabbit GALT starts with the rearrangement of mainly a single $\left(\mathrm{V}_{\mathrm{H}} 1\right)$ gene (Sehgal et al. 1998). Secondary diversification in germinal centres involves both somatic hypermutation and a gene conversion-like mechanism, a process that starts about two weeks after birth (Mage 1998b). The appendix at birth contains no organised B- or T-cell follicular regions. By six weeks old, the appendix contains B-cells in germinal centres and dome regions. No T-cells are found in either of these regions, but are detectable in the interfollicular region. Starting at 9 weeks after birth T-cells are present in domes and later in follicles. These changes may correspond to changes in function (Mage 1998b). Sacculus rotundus is another component of GALT in rabbits with a very similar structure and probably function as the appendix. The other lymphoid organs in rabbits are similar in terms of ontogeny, structure and function to their counterparts in other mammals. Interestingly, the components of GALT are the specific site of the endogenous development of E. coecicola (see above).

The most thorough study in rabbits was performed by Renaux et al. (2003), who studied various immunological parameters after a primary infection with $E$. intestinalis. They noted transient increase in the percentage of intestinal CD4+ lymphocytes and MLN CD8+, 14 days postinoculation (DPI) and strong increasing in the percentage of intestinal CD8+ cells, from 14 DPI onwards. Extensive infiltration of lamina propria with CD8+ lymphocytes was observed 14 DPI. The specific lymphocyte proliferation induced in vitro by parasite antigens was obtained from MLN cells, but not from splenocytes. The specific IgG titres in the serum were only slightly enhanced. The authors concluded that protection against infection is due to an effective mucosal immune response, while systemic responses increase only after successive infections and are only reflections of repeated encounters with parasite antigens.

Pakandl et al. (2008a) performed a comparative study of the immune response elicited by infection with the highly immunogenic coccidium $E$. intestinalis and weakly immunogenic species E. flavescens. The only apparent difference in the immune responses was a marked enhancement of the percentage of CD8+ cells in the epithelium of the ileum, the site specific for E. intestinalis, whereas no significant changes were noted after infection with E. flavescens in the caecum. These results suggest the importance of the local immune response.

Pakandl et al. (2008b) studied dependence of the immune response on the age of young rabbits infected with E. intestinalis and E. flavescens. Unlike the antibody re- sponse, the parameters reflecting cellular immunity (total number of leukocytes in MLN, lymphocyte proliferation upon stimulation with specific antigen and the dynamics of CD4+ and CD8+ cell proportions in the intestinal epithelium at the specific site of parasite development) were significantly changed from about 25 days of age onwards. The absence of a significant humoral response may be connected with successive maturation of the immune system (see above). As in older animals, the only marked difference between rabbits inoculated with both coccidia was observed in the dynamics of CD4+ and CD8+ cells in the epithelium of the specific site of parasite development. Significant changes were noted after infection with $E$. intestinalis, but not in rabbits infected with E. flavescens (except CD4+ cells in the rabbits inoculated at 33 days of age). As the immune system of sucklings from about 25 days of age onwards reacts to the infection, this age may be considered in terms of vaccination against coccidiosis.

The immune response to coccidia infection was studied almost exclusively on chicken or mice model and the results were several times reviewed (Wakelin and Rose 1990, Ovington et al. 1995, Rose 1996, Lillehoj 1998, Yun et al. 2000, Lillehoj et al. 2004).

In contrast, there are only few works dealing with immune response of rabbits to coccidiosis. Thus, a detailed comparison of the immune response to the infection of coccidia in rabbits and chicken or mouse models would be difficult. Nevertheless, no fundamental differences were found.

Evidence from experiments performed mostly in chickens or mice implicate that cell-mediated immunity, including very complex network of cytokines, cytotoxic effects and other mechanisms, plays a major role in the protection against coccidiosis. It has been shown that CD4+ T-cells and, for some species of Eimeria, CD8+ T-cells are important in immune responses that limit parasite infection during primary infection. In subsequent infections, parasite reproduction is limited by CD8+ and, to a lesser extent, CD4+ cells (Wakelin and Rose 1990, Rose et al. 1992, Rose 1996, Lillehoj 1998, Schito et al. 1998, Yun et al. 2000, Shi et al. 2001, Lillehoj et al. 2004).

\subsection{IMMUNITY AND MIGRATION OF SPOROZOITES}

Pakandl et al. (2006) noted significantly reduced numbers of sporozoites of E. coecicola in extraintestinal sites (spleen and MLN) and in the appendix of immune rabbits. Similarly, the number of sporozoites of E. intestinalis was markedly lower in the ileal crypts of immune animals as compared with their naïve counterparts.

Indeed, hampering of migration of sporozoites may be considered as one of the mechanisms involved in host defence against coccidia. Such a strategy may be employed due to the specific behaviour of parasites in the host organism. 
The relation between host immune status and migration of sporozoites was more thoroughly studied in chicken coccidia. IELs, and perhaps macrophages, are involved in the sporozoite migration in chickens and rabbits (see above). These cells seem to play a dual role since they act as local defenders against invading coccidia (Lillehoj 1989, Lillehoj and Bacon 1991, Lillehoj and Trout 1996). The penetration of sporozoites can be affected by the host immune status. In E. tenella, Rose et al. (1984) noted a marked reduction in the numbers of developing parasites in immune chickens as compared to their nonimmune counterparts. Their experiments showed that this effect was due, at least partially, to the failure of sporozoites transported by IELs to be transferred to crypt enterocytes. Riley and Fernando (1988) found that in immune birds, as compared to nonimmune, a significantly greater number of IELs harbouring sporozoites of E. maxima tended to remain in the lamina propria rather than to migrate to the crypts.

\subsection{IMMUNOGENICITY}

Although the immune response to coccidiosis was not extensively studied using immunological methods in rabbits, some studies using oocyst production after challenge infection as a criterion may be considered. Coudert et al. (1993) showed that E. intestinalis is strongly immunogenic, as the inoculation of 6 oocysts reduced the oocyst output by about $60 \%$ after challenge. The oocysts output was fully suppressed in animals inoculated with 600 or more oocysts. Similar results were obtained as regards clinical signs of illness. In contrast, E. flavescens (Norton et al. 1979) and E. piriformis (Coudert, pers. comm.) are weakly immunogenic. Based on oocyst output and in some cases weight gains after challenge, other species, such as E. irresidua (Norton et al. 1979), E. media (Licois et al. 1994), E. magna (Drouet-Viard et al. 1997a) could be considered as middle immunogenic.

From totally 11 coccidian species of rabbit, 10 (except E. exigua) were found in family rabbitries in the Czech Republic. This spectrum of species occurs mostly in rabbits after weaning. In older animals, however, E. flavescens and E. piriformis were predominantly found and the other species were usually rare or only small numbers of oocysts was revealed by coprological examination (Pakandl, unpubl.). Perhaps low immunogenicity of E. flavescens and E. piriformis enables them to reproduce several times in the same rabbits.

\section{Application of MOlecular biology Methods}

Compared with chicken coccidia, there are indeed few articles dealing with application of molecular biology methods in rabbit coccidia. Ceré et al. (1995) performed a genetic polymorphism study. The comparative analysis of the RAPD-generated fingerprints did not allow the establishment of a phylogeny, but the method is on princi- ple useable as a diagnostic tool. In E. media, it was even possible to differentiate the strains obtained from single oocysts. Ceré et al. (1996) also developed very specific and sensitive method to identify E. media oocysts.

Kvíčerová et al. (2008) performed a phylogenetic study involving all eleven valid species of rabbit coccidia. The results revealed the monophyly of rabbit coccidia and divided rabbit coccidia into two sister lineages, corresponding to the presence/absence of the oocyst residuum. Two species localised in the large intestine, E. flavescens and E. piriformis, are also closely related. The other morphological or biological traits did not explicitly correlate with the phylogeny of rabbit coccidia.

\section{Prevention}

\subsection{ZOOHYGIENe}

Clearly, good hygienic conditions, when oocysts are removed from the rabbit facility sooner than they finish sporulation, could theoretically prevent coccidiosis. In praxis, it is impossible to remove all oocysts, but significant reduction of their number in the environment may reduce infective doses and hence clinical signs of disease. Moreover, daily infection with small doses is the best way to obtain an important degree of immunity. The technology of rabbit production may impair even the species composition of coccidia. In the modern rabbit industry in France, for example, only E. magna, E. media and $E$. perforans are present in rabbit broilers (Coudert, pers. comm.). However, rabbit producers cannot rely only on good hygiene and prevention using anticoccidial drugs is currently the only way used in praxis.

\subsection{Chemoprophylaxis}

Coccidiosis is mainly controlled by prophylaxis with different anticoccidical drugs. In praxis, three anticoccidial drugs are currently widely used in rabbits: salinomycin, robenidine and Lerbek. Since the end of 2008, diclazuril is now authorised as feed additive for rabbit in France, Italy and Spain. Nevertheless, other drugs exist that are efficacious against rabbit coccidia. The mean, and almost only, model to develop new anticoccidial drugs are chicken coccidia. Some of the drugs used to control chicken coccidiosis are, however, not efficient against rabbit coccidia. An overview is summarised in Table 4.

Anticocidials are usually mixed in feeding pellets, but if application of some drugs, such as sulphonamides or toltrazuril, in drinking water is possible, it may be advantageous for small rabbitries.

The drugs listed in Table 4, except sulphonamides, can be used only for prevention, while sulphonamides are currently used primarily for treatment of coccidiosis outbreak. However, the treatment is usually not very successful when clinical signs of coccidiosis already appear regardless the drug used. 
Table 4. Anticoccidial drugs efficient and nonefficient against rabbit coccidiosis.

a) efficient

\begin{tabular}{|c|c|}
\hline Drug & Reference \\
\hline decoquinate & Coudert 1978 \\
\hline diclazuril & Vanparijs et al. 1989a, b \\
\hline formolsulphathiazol $^{*}$ & Coudert 1978 \\
\hline $\begin{array}{l}\text { metichlorpindol/methyl- } \\
\text { benzoquate (Lerbek) }\end{array}$ & $\begin{array}{l}\text { Peeters et al. } 1979 \text { b, } 1982,1983 \\
\text { Joyner et al. } 1983 \\
\text { Varga } 1982 \\
\text { Coudert } 1978\end{array}$ \\
\hline monensin ${ }^{* *}$ & $\begin{array}{l}\text { Fitzgerald } 1972 \\
\text { Gwyther and Dick } 1976 \\
\text { Sambeth and Raether } 1980\end{array}$ \\
\hline narasin & Peeters et al. 1981 \\
\hline robenidine ${ }^{* *}$ & $\begin{array}{l}\text { Coudert } 1978 \\
\text { Peeters et al. } 1979 \text { a, } 1980,1983 \\
\text { Peeters and Halen } 1980\end{array}$ \\
\hline salinomycin & $\begin{array}{l}\text { Lämmler and Hein } 1980 \\
\text { Coudert } 1981 \\
\text { Kutzer et al. } 1981 \\
\text { Okerman and Moermans } 1980 \\
\text { Peeters et al. } 1982 \\
\text { Varga } 1982 \\
\text { Sambeth and Raether } 1980\end{array}$ \\
\hline sulphadimethoxine* & Coudert 1981 \\
\hline sulphadimidine/diaveridine* & Daněk et al. 1978 \\
\hline sulphaquinoxaline* & $\begin{array}{l}\text { Chapman } 1948 \\
\text { Joyner et al. } 1983 \\
\text { Kutzer et al. } 1981\end{array}$ \\
\hline $\begin{array}{l}\text { sulphaquinoxaline/ } \\
\text { pyrimethamine }\end{array}$ & Gómez-Bautista and Rojo-Vázquez 1986 \\
\hline toltrazuril & Peeters and Geeroms 1986 \\
\hline
\end{tabular}

${ }^{*}$ sulphonamides (see the remark in the text); ${ }^{* *}$ contradictory results (see part b)

Although anticoccidial drugs can assure relatively reliable and cheap coccidiosis control, their use is not well accepted by public. Moreover, they have some disadvantages, such as negative impact on the environment because of their excretion in faeces, which are subsequently used as fertiliser. The drugs are also absorbed into the meat, having a negative impact on this product. Application of some of these drugs is also risky due to their toxicity for hosts. Moreover, resistance to anticoccidial drugs has appeared in chicken and rabbit coccidia. Vaccination with live attenuated lines of coccidia is another method for the control of coccidiosis, which is becoming popular in farming of domestic fowl.

\subsection{VACCINATION}

Precocious lines, exhibiting significantly reduced pathogenicity, were selected in six rabbit coccidia, including the species relevant in terms of pathogenicity. Perhaps an b) less efficient or nonefficient

\begin{tabular}{ll}
\hline Drug & Reference \\
\hline amprolium & Fitzgerald 1972 \\
amprolium/ ethopabate & Joyner et al. 1983 \\
buquinolate & Peeters and Halen 1979a \\
clopidol & Bedrník and Martinez 1976 \\
furazolidone & Bedrník and Martinez 1976 \\
lasalocid & Bedrník and Martinez 1976 \\
methylbenzoquate & Sambeth and Raether 1980 \\
& Joyner et al. 1983 \\
metichlorpindol & Peeters and Halen 1979b \\
& Bedrník and Martinez 1976 \\
monensin** & Joyner et al. 1983 \\
nicarbazine & Peeters and Halen 1979a, 1980 \\
& Peeters et al. 1980 \\
nitrofurazone/furazolidone & Coudert 1978 \\
robenidine** & Coudert 1978 \\
(liver coccidiosis) & Bedrník and Martinez 1976 \\
sulphaquinoxaline/ & Joyner et al. 1983 \\
pyrimethamine*** & Peeters et al. 1982 \\
\hline
\end{tabular}

${ }^{*}$ sulphonamides (see the remark in the text); ${ }^{* *}$ contradictory results (see part a)

exception is the relatively rare species E. irresidua and E. stiedai.

Vaccination trials were preformed by Drouet-Viard et al. (1997a, b) with a precocious line of E. magna. Vaccination both per os or using spray dispersion of oocysts into nest boxes gave satisfactory results. However, the selection of attenuated lines is still far from the development of a vaccine, including testing of its efficacy, pathogenicity and safety, registration, production and distribution to customers. To my knowledge, nobody in all over the world is currently purposing to continue this work due to the considerable financial means required. It may be supposed that other more sophisticated methods of coccidiosis control will eventually be introduced into the poultry industry and perhaps later in rabbit production as well. Development of efficacious methods, alternative to continuous medication with anticoccidial drugs, of rabbit coccidiosis control, is a challenge for future research work.

Acknowledgements. This work was supported by the grant No. 524/05/2328 of the Grant Agency of the Czech Republic and by the research project of the Intitute of Parasitology, BC ASCR (Z60220518). 


\section{REFERENCES}

Al-Attar M.A., Fernando M.A. 1987: Transport of Eimeria necatrix sporozoites in the chicken: effects of irritants injected intraperitoneally. J. Parasitol. 73: 494-502.

Ball S.J., Allen I., Daszak P. 1990: Transfer of extraintestinal stages of Eimeria vermiformis in the mouse. J. Parasitol. 76: 424-425.

Barriga O.O., Arnoni J.V. 1979: Eimeria stiedae: Weight, oocyst output, and hepatic function of rabbits with graded infections. Exp. Parasitol. 48: 407-414.

Barriga O.O., Arnoni J.V. 1981: Patho-physiology of hepatic coccidiosis in rabbits. Vet. Parasitol. 8: 201-210.

Bedrník P., Martinez J.J. 1976: [Efficacy of different coccidiostatics on intestinal species of rabbit coccidia.] Veterinaria SPOFA 4: 164-174. (In Czech.)

Bombeke A., Okerman F., Moermans R. 1977: La valeur des coccidiostatiques Whitsyn 10 et Coyden 25 dans les aliments pour lapins de boucherie. Rev. Agric. 3: 749-760.

Carvalho J.C. 1942: Eimeria neoleporis n. sp. occurring naturally in the cottontail and transmissible to the tame rabbit. Iowa State Coll. J. Sci. 18: 103-134.

Ceré N., Humbert J.F., Licois D., Corvione M., Afanassieff M., Chanteloup N. 1996: A new approach for the identification and the diagnosis of Eimeria media parasite of rabbit. Exp. Parasitol. 82: $132-138$

Ceré N., Licois D., Humbert J.F. 1995: study of the inter- and intra-specific variation of Eimeria spp. from the rabbit using Random Amplified Polymorphic DNA. Parasitol. Res. 81. 324-328.

ČERnÁ Ž., SÉnAud J. 1971: Some peculiarities of the fine structure of merozoites of Eimeria stiedai. Folia Parasitol. 18: 177-178.

Chapman M.P. 1948: The use of sulphaquinoxaline in the control of liver coccidiosis in domestic rabbits. Vet. Med. 43: 375-379.

Cheissin E.M. 1940: [Rabbit coccidiosis. III. Developmental cycle of Eimeria magna.] Uch. Zap. Len. Gos. Inst. Im. Gertsena 30: 65-91. (In Russian.)

Cheissin E.M. 1947a: [Coccidia of the rabbit intestine.] Uch. Zap. Len. Gos. Inst. Im. Gertsena 51: 1-229. (In Russian.)

Cheissin E.M. 1947b: [New species of rabbit intestinal coccidium.] Dokl. AN SSSR 55: 181-183. (In Russian.)

Cheissin E.M. 1948: [Development of two rabbit intestinal coccidia Eimeria piriformis and E. intestinalis nom. nov.] Uch. Zap. Karelo-Finsk. Univ. III, 3: 179-187. (In Russian.)

Cheissin E.M. 1960: [Cytological observation of the life cycles of rabbit coccidia.] In: Voprosy tsytologii i protistologii 1960. Izdatelstvo AN SSSR, Moskva-Leningrad, pp. 258-276. (In Russian.)

Cheissin E.M. 1967: [Life cycles of the coccidia of domestic animals.] Izdatelstvo Nauka, Leningrad, 192 pp. (In Russian.)

Cheissin E.M. 1968: On the distinctness of the species Eimeria neoleporis Carvalho, 1942 from the cottontail rabbit Sylvilagus floridanus mearnsii and Eimeria coecicola Cheissin, 1947 from the tame rabbit Oryctolagus cuniculus. Acta Protozool. 6: 5-12.

Clark W.M., Hammond D.M. 1969: Development of Eimeria auburnensis in cell cultures. J. Protozool. 14: 663-674.

Coudert P. 1978: Evaluation comparative de l'efficacité de 10 medicaments contre 2 coccidioses graves du lapin. Comm. No. 31, Journées de la Recherche Cunicole, Toulouse, avril 1978.

Coudert P. 1981: Chemoprophylaxe von Darm- und Gallengangskokzidiosen beim Kaninchen. 4. Tagung der Fachgruppe Kleintierkrankheiten in Verbindung mit dem Institut für Kleintierzucht der Fal und der Deutschen Gruppe der WRSA, Celle, 18.-20. Juni 1981, pp. 106-121.
Coudert P., Licois D., Drouet-Viard F. 1995: Eimeria species and strains of the rabbits. In: J. Eckert, R. Braun, M.W. Shirley and P. Coudert (Eds.), Guidelines on techniques in coccidiosis research. European Commission, Directorate-General XII, Science, Research and Development Environment Research Programme, pp. 52-73.

Coudert P., Licois D., Provôt F., Drouet-Viard F. 1993: Eimeria $\mathrm{sp}$. from rabbit (Oryctolagus cuniculus): pathogenicity and immunogenicity of Eimeria intestinalis. Parasitol. Res. 79: 186-190.

Coudert P., Naciri M., Drouet-Viard F., Licois D. 1991: Mammalian coccidiosis: natural resistance of suckling rabbits. 2nd Conference COST-Action 1989, 2-5 April 1991, Münchenwiler, Switzerland.

Daněk J., Ševčík B., Štrosová Z., Firmanová A., Vyhnálek J. 1978: The use of Sulfakombin in suppression of rabbit coccidiosis. Biol. Chem. Vet. 24. 151-169.

Danforth H.D., Hammond D.M. 1972: Merogony in multinucleate merozoites of Eimeria magna Pérard, 1925. J. Protozool. 19: 454-457.

Drouet-Viard F., Coudert P., Licois D., Boivin M. 1997a: Acquired protection of the rabbit (Oryctolagus cuniculus) against coccidiosis using a precocious line of Eimeria magna, effect of vaccine dose and age at vaccination. Vet. Parasitol. 69: 197-201.

Drouet-Viard F., Coudert P., Licois D., Boivin M. 1997b: Vaccination against Eimeria magna coccidiosis using spray dispersion of precocious line oocysts in the nest box. Vet. Parasitol. 70: $61-66$

Drouet-Viard F., Licois D., Provôt F., Coudert P. 1994: The invasion of rabbit intestinal tract by Eimeria intestinalis sporozoites. Parasitol. Res. 80: 706-707.

DürR U. 1972: Life cycle of Eimeria stiedai. Acta Vet. Acad. Sci. Hung. 19: 101-103.

Dürr U., Pellérdy L. 1969: The susceptibility of suckling rabbits to infection with coccidia. Acta Vet. Acad. Sci. Hung. 19: $453-462$.

Eckert J., Taylor M., Catchpole J., Licois D., Coudert P., Bucklar H. 1995: Morphological characteristics of oocyts. In: J. Eckert, R. Braun, M.W. Shirley and P. Coudert (Eds.), Guidelines on techniques in coccidiosis research. European Commission, Directorate-General XII, Science, Research and Development Environment Research Programme, pp. 103-119.

Fernando M.A., Rose M.E., Millard B.J. 1987: Eimeria spp. of the domestic fowl: the migration of sporozoites intra- and extraenterically. J. Parasitol. 73: 561-567.

Fitzgerald P.R. 1970: New findings on the life cycle of Eimeria stiedae. J. Parasitol. 56, II, Part 1: 100-101.

Fitzgerald P.R. 1972: Efficacy of monensin or amprolium 1972 in the prevention of hepatic coccidiosis in rabbits. J. Protozool. 19: $332-334$.

Gomez-Bautista M., Rojo-VÁzquez F.A. 1986: Chemotherapy and chemoprophylaxis of hepatic coccidiosis with sulphamethoxine and pyrimethamine. Res. Vet. Sci. 40: 28-32.

Gregory M.W., Catchpole J. 1986: Coccidiosis in rabbits: the pathology of Eimeria flavescens infection. Int. J. Parasitol. 16: $131-145$

Gwyther M.J., Dick J.W. 1976: Efficacy of monensin and sulfaquinoxaline against coccidium, Eimeria stiedai, in rabbits. Poult. Sci. 55: 1594 
HABERKorn A. 1970: Die Entwicklung von Eimeria falciformis (Eimer 1870) in der weissen Maus (Mus musculus). Z. Parasitenkd. 34: 49-67.

HeIN B., LÄmmLer G. 1978: Alteration of enzyme activities in serum of rabbits infected with Eimeria stiedai. Z. Parasitenkd. 57: 199-211.

HоRTon R. J. 1967: The route of migration of Eimeria stiedae (Lindeman, 1865) sporozoites between the duodenum and bile ducts of the rabbit. Parasitology 57: 9-17.

JEFFERS T.K. 1975: Attenuation of Eimeria tenella through selection of precociousness J. Parasitol. 61: 1083-1090.

Jelínková A., Licois D., Pakandl M. 2008: The endogenous development of the rabbit coccidium Eimeria exigua Yakimoff, 1934. Vet. Parasitol. 156: 168-172.

Joyner L.P., Catchpole J., Berret S. 1983: Eimeria stiedai in rabbits: the demonstration of responses to chemotherapy. Res. Vet. Sci. 34: 64-67.

Kogut M.H., Long P.L. 1984: Extraintestinal sporozoites of chicken Eimeria in chickens and turkeys. Z. Parasitenkd. 70: 287-295.

Kutzer E., Leibetseder J., Frey H., Böhm J., Prets H. 1981: Salinomycin, ein neues Antikokzidium in der Kaninchenmast. Wien. Tierärztl. Mschr. 68: 57-64.

Kvíčerová J., PaKandl M., Hypša V. 2008: Phylogenetic relationships among Eimeria spp. (Apicomplexa, Eimeriidae) infecting rabbits: evolutionary significance of biological and morphological features. Parasitology 135: 443-452.

Lämmler G., Hein B. 1980: Prophylaktische Wirksamkheit des Polyäther-Antibiotikums Salinomycin bei der Gallengangscoccidiose des Kaninchens. Berl. Münch. Tierärztl. Wschr. 93: 449-454.

Lawn A.M., Rose M.E. 1982: Mucosal transport of Eimeria tenella in the cecum of the chicken. J. Parasitol. 68: 1117-1123.

Lee E.H., Remmler O., Fernando M.A. 1977: Sexual differentiation in Eimeria tenella (Sporozoa: Coccidia). J. Parasitol. 63: 155-156.

Levine N.D. 1973: Introduction, history and taxonomy. In: D.M. Hammond and P.L. Long (Eds.), The Coccidia. University Park Press, Baltimore, pp. 1-22.

Licois D., Coudert P., Bahagia S., Rossi G.L. 1992: Characterisation of Eimeria species in rabbits (Oryctolagus cuniculus): endogenous development of Eimeria intestinalis Cheissin, 1948. J. Parasitol. 78: 1041-1046.

Licois D., Coudert P., Boivin M., Drouet-Viard F., Provôt F. 1990: Selection and characterization of a precocious line of Eimeria intestinalis, an intestinal rabbit coccidium. Parasitol. Res. 76: 192-198.

Licois D., Coudert P., Drouet-Viard F., Boivin M. 1992: Eimeria perforans and E. coecicola: multiplication rate and effect of acquired protection on the oocyst output. J. Appl. Rabbit Res. 15: 1433-1469.

Licois D., Coudert P., Drouet-Viard F., Boivin M. 1994: Eimeria media: selection and characterization of a precocious line. Parasitol. Res. 80: 48-52.

Licois D., Coudert P., Drouet-Viard F., Boivin M. 1995: Eimeria magna: immunogenicity and selection and characterization of a precocious line. Vet. Parasitol. 60: 27-35.

Licois D., Coudert P., Mongin P. 1978a: Changes in hydromineral metabolism in diarrhoeic rabbit. 1. A study of the changes in water metabolism. Ann. Rech. Vét. 9: 1-10.

Licois D., Coudert P., Mongin P. 1978b: Changes in hydromineral metabolism in diarrhoeic rabbit. 2. A study of the modification of electrolyte metabolism. Ann. Rech. Vét. 9: 453-464.
Licois D., Guillot J.F. 1980: Évolution de nombre de collibacilles chez les laperaux atteints de coccidiose intestinale. Rec. Med. Vét. 156: 555-560.

LiLlehoJ H.S. 1989: Intestinal intraepithelial and splenic natural killer cell responses to eimerian infections in inbred chickens. Infect. Immun. 57: 1879-1884.

Lillehoj H.S. 1998: Role of T lymphocytes and cytokines in coccidiosis. Int. J. Parasitol. 28: 1071-1081.

LillehoJ H.S., BACON L.D. 1991: Increase of intestinal intraepithelial lymphocytes expressing CD8 antigen following challenge infection with Eimeria acervulina. Avian Dis. 35: 294-301.

Lillehoj H.S., Min W., Dalloul R.A. 2004: Recent progress on the cytokine regulation of intestinal immune response to Eimeria. Poult. Sci. 83: 611-623.

Lillehoj H.S., Trout J.M. 1996: Avian gut-associated lymphoid tissues and intestinal immune responses to Eimeria parasites. Clin. Microbiol. Rev. 9: 349-360.

Long P.L., Millard B.J. 1979: Rejection of Eimeria by foreign hosts. Parasitology 78: 239-247.

Mage R.G. 1998a: Diversification of rabbit VH genes by geneconversion-like hypermutation mechanisms. Immunol. Rev. 162: 49-54.

MAGE R.G. 1998b: Immunology of lagomorphs. In: P.P. Pastoret, P. Griebel, H. Bazin and A. Govaerts (Eds.), Handbook of Vertebrate Immunology. Academic Press, London, pp. 223-260.

Norton C.C., Catchpole J., Joyner L.P. 1979: Redescriptions of Eimeria irresidua Kessel \& Jankiewicz, 1931 and E. flavescens Marotel \& Guilhon, 1941 from the domestic rabbit. Parasitology 79: 231-248.

Okerman F., Moermans R.J. 1980: L'ifluence du coccidiostatique Salinomycine en tant qu'additif des aliments composés, sur le résultants de production des lapins de chair. Rev. Agric. 33: 1311-1321.

Ovington K.S., Alleva L.M., Kerr E.A. 1995: Cytokines and immunological control of Eimeria spp. Int. J. Parasitol. 25: 1331-1351.

PaKandL M. 1988: Description of Eimeria vejdovskyi sp.n. and redescription of Eimeria media Kessel, 1929. Folia Parasitol. 35: $1-9$.

PAKANDL M. 2005: Selection of a precocious line of the rabbit coccidium Eimeria flavescens Marotel and Guilhon (1941) and characterisation of its endogenous cycle. Parasitol. Res. 97: 150-155.

Pakandl M., Černí F., Coudert P. 2003: The rabbit coccidium Eimeria flavescens Marotel and Guilhon, 1941: an electron microscopic study of its life cycle. Parasitol. Res. 91: 304-311.

PaKandl M., Coudert P. 1999: Life cycle of Eimeria vejdovskyi Pakandl, 1988: electron microscopy study. Parasitol. Res. 85: 850-854.

Pakandl M., Coudert P., Licois D. 1993: Migration of sporozoites and merogony of Eimeria coecicola in the gut-associated lymphoid tissue. Parasitol. Res. 79: 593-598.

Pakandl M., Drouet-Viard F. Coudert P. 1995: How do sporozoites of rabbit Eimeria species reach their target cells? C. R. Acad. Sci. Paris, Life Sciences, 318: 1213-1217.

Pakandl M., Eid Ahmed N., Licois D., Coudert P. 1996b: Eimeria magna Pérard, 1925: life cycle studies with parental and precocious strains. Vet. Parasitol. 65: 213-222.

Pakandl M., Gaca K., Drouet-Viard F., Coudert P. 1996a: Eimeria coecicola: endogenous development in gut-associated lymphoid tissue. Parasitol. Res. 82: 347-351.

Pakandl M., Gaca K., Licois D., Coudert P. 1996c: Eimeria media Kessel, 1929: comparative study of endogenous devel- 
opment between precocious and parental strains. Vet. Res. 27: 465-472.

Pakandl M., Hlásková L. 2007: The reproduction of Eimeria flavescens and Eimeria intestinalis in suckling rabbits. Parasitol. Res. 101: 1435-1437.

Pakandl M., Hlásková L., Poplštein M., Chromá V., VodičKa T., Salát J., Mucksová J. 2008a: Dependence of the immune response to coccidiosis on the age of rabbit suckling. Parasitol. Res. 103: 1265-1271.

Pakandl M., Hlásková L., Poplštein M., Nevečeřalová M., VodičKa T., SAlát J., Mucksová J. 2008b: Immune response to rabbit coccidiosis: a comparison between infections with Eimeria flavescens and Eimeria intestinalis. Folia Parasitol. 55: $1-6$.

Pakandl M., Jelínková A. 2006: The rabbit coccidium Eimeria piriformis: selection of a precocious line and life-cycle study. Vet. Parasitol. 137: 351-354

Pakandl M., Licois D., Coudert P. 2001: Electron microscopy study on sporocysts and sporozoites of parental strains and precocious lines of rabbit coccidia Eimeria intestinalis, E. media and E. magna. Parasitol. Res. 87: 63-66.

Pakandl M., Sewald B., Drouet-Viard F. 2006: Invasion of the intestinal tract by sporozoites of Eimeria coecicola and Eimeria intestinalis in naive and immune rabbits. Parasitol. Res. 98: 310-316.

Peeters J.E., Charlier G., Antoine O., Mammerickx M. 1984a: Clinical and pathological changes after Eimeria intestinalis infection in rabbits. Zbl. Vet. Med. B 31: 9-24.

Peeters J.E., Geeroms R. 1986: Efficacy of toltrazuril against intestinal and hepatic coccidiosis in rabbits. Vet. Parasitol. 22: $21-35$.

Peeters J.E., Geeroms R., Antoine O., Mammerickx M., Halen P. 1981: Efficacy of narasin against hepatic and intestinal coccidiosis in rabbits. Parasitology 83: 293-301.

Peeters J.E., Geeroms R., Molderez J., Halen P. 1982: Activity of clopidol methylbenzoquate, robenidine and salinomycin against hepatic coccidiosis in rabbits. Zbl. Vet. Med. B 29: 207218.

Peeters J.E., Geeroms R., Vaweryck H., Bouquet Y., Lampo P., HaLen P. 1983: Immunity and effect of clopidol/methylbezoquate and robenidine before and after weaning on rabbit coccidiosis in the field. Res. Vet. Sci. 35: 211-216.

Peeters J.E., Halen P. 1979a: [Efficacy of some coccidiostatics against the intestinal coccidiosis in rabbits. 1. Amproluim-ethopabat and metichlorpindol.] Vl. Diergen. Tijdschr. 48: 299-306. (In Flemish.)

Peeters J.E., Halen P. 1979b: [Efficacy of some coccidiostatics against intestinal coccidiosis in rabbits. 2. Pancoxin plus and Statyl.] Vl. Diergen. Tijdschr. 48: 387-395. (In Flemish.)

Peeters J.E., Halen P. 1980: Field trials with the coccidiostatics metichlorpindol and robenidine in a rabbit farm. Ann. Rech. Vét. 11: 49-55.

Peeters J.E., Halen P., Meulemans G. 1979a: Efficacy of robenidine in the prevention of rabbit coccidiosis. Br. Vet. J. 135: 349-354.

Peeters J.E., Janssen-Geeroms R., Halen P. 1980: Effet des anticoccidians Coyden 25, Cycopstat et Whytsin 10 sur l'excrétion oocystale dans l'élavage cunicole industriel. Rév. Agric. 33: 845-855.

Peeters J.E., Janssen-Geeroms R., Lampo P., Halen P. 1979b: Synergistic anticoccidial activity of metichlorpindol and methylbenzoquate in rabbits. Ann. Med. Vét. 123: 573-579.
Peeters J.E., Pohl P., Charlier G. 1984b: Infectious agents associated with diarrhoea in commercial rabbits: a field study. Ann. Rech. Vét. 15: 335-340.

Pellérdy L.P. 1974: Coccidia and Coccidiosis. Akadémiai Kiadó, Budapest, 959 pp.

Pellérdy L.P., Babos S. 1953: Untersuchungen über die endogene Entwicklung sowie pathologische Bedeutung von Eimeria media. Acta Vet. Acad. Sci. Hung. 3: 173-178.

Pellérdy L.P., DÜrR U. 1970: Zum endogenen Entwicklugszyklus von Eimeria stiedai (Lindemann, 1865) Kisskalt, Hartman 1907. Acta Vet. Acad. Sci. Hung. 20: 227-244.

Renaux S., Drouet-Viard F., Chanteloup N.K., Le Vern Y., Kerboef D., Pakandl M., Coudert P. 2001: Tissues and cells involved in the invasion of the rabbit intestinal tract by sporozoites of Eimeria coecicola. Parasitol. Res. 87: 98-106.

Renaux S., Quéré P., Buzoni-Gatel D., Sewald B., Le Vern Y., Coudert P., Drouet-Viard F. 2003: Dynamics and responsiveness of T-lymphocytes in secondary lymphoid organs of rabbits developing immunity to Eimeria intestinalis. Vet. Parasitol. 110: 181-195.

Riley D., Fernando M.A. 1988: Eimeria maxima (Apicomplexa): a comparison of sporozoite transport in naive and immune chickens. J. Parasitol. 74: 103-110.

Roberts W.L., Hammond D.M., Anderson L.C., Speer C.A. 1970: Ultrastructural study of schizogony in Eimeria callospermophili. J. Protozool. 17: 584-592.

Rose M.E. 1973: Immunity. In: D.M. Hammond and P.L. Long (Eds.), The Coccidia. University Press, Baltimore, pp. 295-241.

Rose M.E. 1996: Immunity to coccidia. In: T.F. Davidson, T.R. Morris and L.N. Payne (Eds.), Poultry Immunology. Poultry Sci. Symp. Series, Vol. 24, pp. 265-299.

Rose M.E., Lawn A.M., Millard B.J. 1984: The effects of immunity on the early events in the life-cycle of Eimeria tenella in the cecal mucosa of the chickens. Parasitology 88: 199-210.

Rose M.E., Hesketh P., Wakelin D. 1992: Immune control of murine coccidiosis - CD4+ and CD8+ lymphocytes-T contribute differentially in resistance to primary and secondary infections. Parasitology 105: 349-354.

RUtherFord R.L. 1943: The life cycle of four intestinal coccidia of the domestic rabbit. J. Parasitol. 29: 10-32.

Ryley J.F., Robinson T.E. 1976: Life cycle studies with Eimeria magna Pérard, 1925. Z. Parasitenkd. 50: 257-275.

Sambeth W., Raether W. 1980: Prophylaktischer Effekt von Salinomycin gegen die Kokzidiose des Kaninchens. Zbl. Vet. Med. B 27: 446-458.

SAmpSon J.R., Hammond D.M. 1970: The fine structure of the early stages of Eimeria alabamensis in cell cultures. J. Protozool. 17: 49A.

Schito M.L., Сhobotar B., Barta J.R. 1998: Cellular dynamics and cytokine responses in BALB/c mice infected with Eimeria papillata during primary and secondary infections. J. Parasitol. 84: $328-337$.

Sehgal D., Schiaffella E., Anderson A.O., Mage R.G. 1998: Analyses of single B cells by polymerase chain reaction reveal rearranged $\mathrm{V}_{\mathrm{H}}$ with germline sequences in spleens of immunized adult rabbits: implications for $\mathrm{B}$ cell repertoire maintenance and renewal. J. Immunol. 161: 5347-5356.

SÉNAUd J., ČERNÁ Ž. 1969: Étude ultrastructurale des mérozoites et de la schizogonie des coccidies (Eimeriina): Eimeria magna (Pérard, 1925) de l'intestin des lapins et Eimeria tenella (Railliet et Lucet, 1891) des caecums des poulets. J. Protozool. 16: 155-165. 
Shi M.Q., Huther S., Burkhardt E., Zahner H. 2001: Lymphocyte subpopulations in the caecum mucosa of rats after infections with Eimeria separata: early responses in naive and immune animals to primary and challenge infections. Int. J. Parasitol. 31: 49-55.

Shirley M.W., Harvey D.A. 1996: Eimeria tenella: infection with a single sporocyst gives a clonal population. Parasitology 112: 523-528.

Shirley M.W., Long P.L. 1990: Control of coccidiosis: immunisation with live vaccines. In: P.L. Long (Ed.), Coccidiosis of Man and Domestic Animals. CRC Press, Boston, pp. 321-341.

Smetana H. 1933a: Coccidiosis of the liver of rabbits: experimental study of the mode of infection of the liver by sporozoites. Arch. Pathol. 15: 330-339.

Smetana H. 1933b: Coccidiosis of the liver of rabbits: experimental study of the histogenesis of coccidiosis of the liver. Arch. Pathol. 15: 516-536.

Smith T.G., Walliker D., Ranford-Cartwright L.C. 2002: Sexual differentiation and sex determination in the Apicomplexa. Trends Parasitol. 18: 315-323.

Speer C.A., Hammond D.M. 1970: Development of Eimeria larimensis from the Uinta ground squirrel in cell cultures. Z. Parasitenkd. 35: 105-118.

Speer C.A., Hammond D.M., Anderson L.C. 1970: Development of Eimeria callospermophili and Eimeria bilamellata from the Uinta ground squirrel, Spermophilus armatus in cultured cells. J. Protozool. 17: 274-284.

Received 4 June 2009
Speer C.A., Hammond D.M., Elsner Y.Y. 1973: Further asexual development of Eimeria magna merozoites in cell culture. J. Parasitol. 59: 613-623.

Streun A., Coudert P., Rossi G.L. 1979: Characterization of Eimeria species. II. Sequential morphologic study of the endogenous cycle of Eimeria perforans (Leuckart, 1879; Sluiter and Swellengrebel, 1912) in experimentally infected rabbits. Z. Parasitenkd. 60: 37-53.

Vanparijs O., Desplenter L., Marsboom R. 1989a: Efficacy of diclazuril in the control of intestinal coccidiosis in rabbits. Vet. Parasitol. 34: 185-190.

Vanparijs O., Hermans L., van der Flaes L., Marsboom R. 1989b: Efficacy of diclazuril in the prevention and cure of intestinal and hepatic coccidiosis in rabbits. Vet. Parasitol. 32: $109-117$.

VARGA I. 1982: Large-scale management and parasite populations: Coccidia in rabbit. Vet. Parasitol. 11: 69-84.

Vitovec J., Pakandl M. 1989: The pathogenicity of rabbit coccidium Eimeria coecicola Cheissin, 1947. Folia Parasitol. 36: 289-293.

Wakelin D., Rose M.E. 1990: Immunity to coccidiosis. In: P.L. Long (Ed.), Coccidiosis of Man and Domestic Animals. CRC Press, Boston, pp. 281-306.

Weinstein P.D., Anderson A.O., Mage R.G. 1994: Rabbit IgH sequences in appendix germinal centers: $\mathrm{VH}$ diversification by gene conversion-like and hypermutation mechanism. Immunity 1: 647-659.

Yun C.H., LillehoJ H.S., LillehoJ E.P. 2000: Intestinal immune response to coccidiosis. Dev. Comp. Immunol. 24: 303-324.

Accepted 12 August 2009 